\title{
DEN RÄTTA PLATSEN. NAGRA ANTECKNINGAR OM MUSEER, MEDIER OCH MINNANDET
}

\section{Anders Björnsson}

De historiska museernas särart $i$ jämförelse med andra platser där vi aterkallar minnet av det forflutna har kommit i blickfänget genom de senaste årens stora monumentalprojekt.

Den postmodernistiska museididaktiken sätter det emotiva och känsloladdade främst, men därigenom risikerar man att forbise museernas roll som kunskapsformedlare och forskningsmiljöer. Emancipation, inte identifikation, är det kritiska historiestudiets metodologiska grundsten.

I

Det är med stor tvekan som jag tar till orda i ett ämne där min kompetens är lekmannens, men där mitt uppträdande kan förväxlas med expertens. Egentligen har jag sagt allt jag har att säga $i$ ett tidigare sammanhang (Björnsson 1991). Museivärlden var måttligt förtjust den gången. Här tillför jag nu ingenting i sak. Risken är väl snarare att jag förargar i onödan, och för mig är ett institutionaliserat outsiderskap verkligen ingenting att be om.

Förstå mig rätt. Jag är journalist. Journalister lockas gärna - alltför gärna att kreera expertroller. Den initierade kommentaren, som kanske inte är något annat än en väl tillskuren kliché, tillämp- bar på många sakområden, får en auktoritet den kunde ha haft blott om den byggt på förvärvad sakkunskap. Den kritiska hållningen, som journalisten - idealt sett - delar med andra professionella, t ex vetenskapsmannen, tar lätt formen av ihållande, självbekräftande kampanjer. Och ändå är det ju så att pretentionen på professionalitet för journalisten knappast sträcker sig utanför den mediala sfären; men det är å andra sidan just inom denna sfär som de mest fatala förväxlingsnumren utförs! TV-sända pratshower där journalister frågar ut varandra och förlöjligar alla andra har för länge sedan blivit en medial normalitet. Man undrar om ett återtåg från denna iscensatta låtsasverklighet någonsin kommer att vara möjligt. 
94 Har nu den mediala kulturens många besynnerligheter med ämnet för dagen att göra? Kanske i alla fall.

Se det så här: Det tycks mig obestridligt att de stora mediernas sätt att beskriva och gestalta olika verkligheter med stor kraft har trängt in också på andra kulturella områden. Risken vi löper är förstås standardisering. Att exempelvis det som görs inom ramen för offentliga kulturinstitutioner, för att försvara och motivera existensen av dessa institutioner, till vilka vi utan vidare kan räkna museerna, kommer att utspelas i det mediala landskapet och på de villkor som gäller där. Och vidare: att museerna då bara blir en plats av flera i detta - lättillgängliga men svåröverskådliga - medielandskap, utan någon principiell och påvisbar särart, som ger dem en tydlig lokalisering.

Detta ser jag som en hotbild; en av flera. Medialiseringen alltså. Själv gör jag vad jag kan för att skillnaden mellan journalistrollen och expertrollen inte ska raderas ut. Det är inte alltid lätt. Jag ombads nyligen att skriva ett bidrag till en årsbok för svenskt arkivväsen (Björnsson 1994a). Jag fann en fyndig rubrik men fick disketten tillbaka med en sur kommentar plus rekommendationen att jag borde studera Arkivlagen med kommentarer! Sur och sund. För vad är alternativet? Ett löst och oansvarigt tyckande. Den hållning jag skulle vilja slåss för är istället den engagerade och intresserade lekmannens. Den är riskfylld och den kan inte gärna intas utan respekt för sakkunskapen och inte heller utan en vilja till ömsesidig dialog.

För mig har det varit viktigt att försöka definiera och precisera vari det historiska museets särart - om vi så vill, dess komparativa fordel - består. Jag har alltså sagt det förut: det kan inte vara något annat än föremålet - det döda föremålet.

\section{II}

Så vad är ett museum? När jag var smågrabb brukade jag på söndagar följa med min far in till Stockholms Central. Där fanns en monter med en modell av ett svart ånglok $\mathrm{i}$ den stora passagerarhallen. Man stoppade i en femöring och den gick igång under några minuter. Själva föremålet var dött och sterilt och på något sätt ryckt ur sitt sammanhang. Omgivningen var stökig. Dessutom var ånglokens tid förbi, även om man fortfarande kunde se dem transportera sopor till tippen ute i Hässelby: "Silverpilen" kallades ekipaget med de vita vagnarna. Ändå upplevde jag platsen som den rätta, eftersom jag så många gånger återvände för att se och beskåda det som fanns i den där montern, utan att det på något sätt blev pedagogiskt tillrättalagt vad det var jag såg och uppfattade.

Jo, ibland följde min farfar med. Han hade varit vid de enskilda järnvägarna när seklet var ungt och hörde till pionjärerna inom tjänstemännens fackliga organisering; skrev även en förbundshistorik, som seden ännu var (Björnsson 1962). Farfar kunde berätta om den tid då spåren ännu gick in i den stora hallen och om arbetet med sammanbindningsbanan söderut. Idag ska det «tredje spåret» läggas, och breddningen skär rätt in $\mathrm{i}$ en existerande historisk miljö. Vi, som har sett städer gå under genom klåfingriga ingrepp, har lätt att intuitivt värja oss mot projekt av det här slaget: det är fel tid, det är fel plats. Vi återvänder inte dit utan sorg i själen.

Ändå går det naturligtvis att uppfatta både ångloksmodellen och Riddarholmen 
som "museala", i den meningen att de fryser ett historiskt moment, en epok, ett livssammanhang, samtidigt som den destruktiva moderniteten dundrar på. En antikvarisk huvuduppgift (jag återkommer till det) måste rimligen vara att bevara genuina miljöer, där historien ännu har en chans att leva. Men den uppgiften sammanfaller knappast med museernas verksamhet och kan heller inte göra det.

För vem vill beteckna Riddarholmen som ett museum? Där pågår idag annan verksamhet än den antikvariska, även om byggnaderna - palatsen, ämbetsverken kan vara mycket äldre än saker som vi finner i ett historiskt museum. Åldern kan uppenbarligen inte vara något avgörande - särskiljande - kriterium på vad som är musealt eller inte. Det avgörande är förstås om det ännu är i bruk.

Det som finns i ett museum har upphört att vara i bruk. Där historien lever - eller försöker överleva - finns det inte bruk for ett museum. (Samtidsdokumentation är till för framtida bruk eller uttryck för antropologisk beskäftighet.) Och där det finns ett museum kan vi inte forvänta oss att historien ska leva. Konkret betyder det att källarvalven i hessensteinska palatset blir museiföremål först i det ögonblick som de plockas ner för att ge rum år det "tredje spåret".

Jag är medveten om att min definition är både operationell och lekmannamässig, men finns det en annan, en bättre? Den rymmer en djup paradox: Moderniteten är museets moder. Den fräga jag vill ställa är om postmodernismen är dess dödgrävare.

Tre saker vill jag tala om: föremålen; historien - inte som förfluten tid men som kunskapsform; slutligen estetiken - presentationsformen.
Det slog mig en vacker vårdag för några år sedan, när jag vandrade omkring längs kajerna, att många av Stockholms museer ligger vid vatten. Det kan hända att jag blev bländad av solens reflexer från vattenytan, men när jag kom in på några av de här museerna såg jag nästan ingenting. Det jag såg var ett mörker; och jag vet att mörkret är ett skydd för den som har någonting att vara rädd om. Men mörkret användes också som effekt. Det som skulle ses var svåråtkomligt. Medeltida handskrifter låg på golvet och då fick också besökaren göra det om han ville tyda texten, besvärlig nog ändå.

En tid därefter kom jag till Helsingfors. I domkyrkans krypta - krypta! - visades ritningar av Engel, han som gett den kejserliga empirestaden så många av dess vackraste byggnader. Ritningarna och skisserna var blott till hälften belysta av spotlights; resten låg $\mathrm{i}$ en suggestiv skugga. Allt det ljusa och gula, som gav epoken rymd och framstegsvittring, kunde blott anas under de mäktiga valvbågarna. Man borde medfört ficklampa. Eller kunde man inte ha gjort kopior istället?

Det är en fråga jag har velat ställa länge: Är det så att sakmuseerna är rädda inta bara om utan för sina saker? Kritiken mot föremålsraseriet har ju kommit främst från museerna själva. Publiken uteblev. Men uteblev den för att föremålen fanns? Eller för att den inte fick en chans att ställa de rätta frågorna? Eller för att den inte blev förförd? Antiintellektualismen alltså. Det värsta av alternativen.

Många museer - inte bara de renodlat historiska - visar nu allt mindre av sina bestånd. Naturhistoriska kommer inte 
96 längre att ha någon basutställning; man plockar fram efter behov i glesa utställningssalar. Det är en undergrävande verksamhet. Vad ska man med alla föremål som ändå ingen får se? Det är en fråga som en organisationskonsult en vacker dag kommer att ställa. Räcker det inte med ett mindre antal som kan egga fantasin?

Men mängden, massan är viktig. Materialets storlek avgör om vi kan uppfatta ett mönster.

Ta det här med räfsor, sa Janken Myrdal när jag intervjuade honom under våren (Björnsson 1994b). De var förstås länge ett parodiskt exempel på prylmanin. Likadana, lika fula, lika ointressanta var för sig. Vem är intresserad av statistik över antalet pliggar? utbredningskartor? tillverkningstekniker? Men kanske säger de mer än annat, sådant som inget annat material berättar om.

Om vi nu ser på kvinnoräfsor. Kvinnoräfsor är mindre än mansräfsor. Men fästmöräfsorna är större än vanliga kvinnoräfsor. Vi vet att det är fästmöräfsor, därför att de är målade och målningen sitter kvar. De användes under en enda höskörd, den som föregick giftermålet. De var till för att visas upp. Eller uttryckt på annat sätt: fästmannen ville att den blivande hustrun skulle vara något att visa upp. Det underliggande antagandet är att storleken betyder något. Kanske, säger Myrdal, finner vi här en likhetsmagi. Stor räfsa duktig arbeterska - god skörd. Och kanske var samtiden omedveten om mönstret, ungefär som ingen riktigt uppfattade magin med stora bilar före oljekrisen. Nutiden skulle inte heller ha fått syn på mönstret om inte museerna haft mängder av räfsor, av olika typer, på lager att visa upp.
Här talar vi inte bara om minnesfunktionen utan också om medvetandefunktionen hos de historiska museerna. Det döda făr liv i jakten på kunskap.

Museerna som forskningsmiljöer är oskiljaktiga från museerna som didaktisk miljö. I dagens museer finns massor av material i lårar och kartonger som ingen vårdar. Det är en resursfråga: om de visas för publik kan de inte fă förfaras. Men det är ingen mening med att visa dem, hur vackra de än är (och jag har förstått att fästmöräfsor kan vara mycket vackra), om inte viktiga frågor om den historiska verkligheten ställs. Och det blir i sin tur möjligt bara om museerna etablerar sig som livaktiga forskningsmiljöer. Jag är inte säker på att det är där satsningarna görs idag. I jippot Den Svenska Historien var forskningsanknytningen helt bruten. Ska museerna i fortsättningen ensidigt satsa på förmedling av etablerat vetande blir problemet helt akut.

\section{IV}

Detta för in på min andra punkt: historien. Om vi kan befara att allt färre saker kommer att finnas i de historiska museerna (som resultat av någon befängd företagsekonomisk kalkyl), så är en annan farhåga redan realiserad: det finns inga historiker där. Vi närmar oss $m$ a $o$ en situation där forreträdare för forremålsinriktade discipliner etnologer, arkeologer, konstvetare, kanske en och annan antropolog - har monopoliserat professionen men blir allt mindre intresserade av själva forremålen. Etnologer vill ägna sig åt kulturanalys istället. Museimän utför galanta kulturanalyser av museerna själva som samtidshistoriska miljöer, som en enda jätteartefakt. Vi står inför ett post- 
modernistiskt uppsökande, en trend som på sikt måste hota sakmuseernas legitimitet.

Vad kan historikerna ge museivärlden? Låt mig ta ett exempel från paradutställningen Solen och polstjärnan i Stockholm och Paris (1994).

Den är i allt väsentligt konstvetenskapligt anlagd. Där etableras förbindelser mellan franskt och svenskt inte endast på elitnivån, vilken är en betydande förtjänst; vi får inblickar också i brukssamhällenas länge franskspråkiga miljöer, den vallonska arbetar- och expertimporten, skildrade genom Elias Martins och Per Hilleströms fina akvareller. Men det är på det hela taget en mycket snäll utställning om 1700-talet, som dessutom upphöjer hela seklet till en norm. Samtidigt som den pågick, invigdes en fransk-svensk frimärksutställning i de båda huvudstäderna, där det i katalogen sägs att inget land har varit viktigare för Sverige kulturellt än Frankrike - man glömmer den italienska renässansen, man glömmer den tyska närvaron alltifrån medeltidens hantverk till romantikens och 1800-talets svärmeri för det tyska! Och det finns ett stort hål på Nationalmuseum och Palais Royal: erotiken! 1700-talet är århundradet då erotiken blir synlig, i litteraturen, i politiken. Den avskiljs som en särskild verksamhetsform, den frigörs från kyrkans bann genom den snabba sekulariseringen. Och mycket av detta kommer naturligtvis från Frankrike.

Allt det här missar man med närsynt föremålskunskap. Och inte kommer man mycket längre med kulturanalys.

Jag känner bara till två disputerade historiker med tjänst på svenska museer. Det är en skandal. Det borde vara självklart en huvudregel - att en historiker ska vara chef för ett historiskt museum. Vidare bör de historiska universitetsämnena faktiskt skulle vara lika naturligt för en historiker, ekonom-historiker eller idéhistoriker att välja museibanan som att gå till arkiv eller till utbildningsväsendet efter att ha skrivit sin avhandling.

Historikern bidrar med en unik kompetens: det objektiva, kritiska sanningssökandet. Det ses ibland som något narraktigt, ouppnåeligt. Men det är viktigt att upprätthålla som ideal, särskilt i tider av snabba värderingsförskjutningar och värderelativism. Jag kan skrämmas av att höra en museiutredare säga att museernas traditionella funktioner - samla, vårda, forska, visa - inte längre kan vara mål i sig. Det finns de som säger att det vetenskapliga sanningssökandet inte kan vara mål i sig, utan blott medel för en högre samhällsnytta, exempelvis ekonomisk tillväxt, industriell konkurrenskraft. Om museerna vill ha ett annat mål av staten: vad kan det vara? Nationell stolthet, när den europeiska integrationen nu står för dörren? Ska OS i Lillehammer vara förebilden för museisatsningar i framtiden? Visst finns det mycket som tyder på att det var statsmakternas avsikt med Den Svenska Historien. Och i bakgrunden till Solen och polstjärnan ligger givetvis det sedenmera havererade Volvo-Renault-projektet.

Nej, jag tror inte att man ska ropa på mål som ställs utanför museiverksamheten. Målen bör, liksom på universiteten, inom forskningen, ställas internt. Men det förutsätter två ting:

För det första ämnesmässig mångfald framförallt ett starkt ökat inflöde av fackhistoriker.

För det andra interinstitutionell konkurrens. Istället för att slå ihop två riksmuseer, 
98 ett arkeologiskt och ett etnologiskt, och hoppas att det ska uppstå ett Historiskt Riksmuseum borde man, som Sune Åkerman har pläderat för (Åkerman 1990), skapa ett alternativt, konkurrerande. Det kan t ex ligga på Riddarholmen i Stockholm, en historisk miljö som är nästan intakt. Resurser kan tillföras från den regionala nivån, från en lätt överdimensionerad länsmuseiorganisation.

\section{V}

Min sista punkt: presentationsformen, estetiken. Honnörsordet nummer ett inom museididaktiken idag är identifikation. Den styrande metaforen tycks mig vara hämtad från illusionsteatern: inlevelsen i det som sker på scenen. Sten Rentzhog har formulerat ideologin ytterst blatant: «Det unika med utställningen är det emotionella", säger han.

En utställning ska inte i första hand vända sig till intellektet, utan till känslor och fantasi. Utställningens huvudsyfte är inte att lära ut kunskap, utan att ge en upplevelse (Rentzhog 1994).

En lärodiktare som Brecht ville med sin Verfremdungstheorie och sina lärostycken något annat: det rationella iakttagandet. Vi kan inte leva oss in i Den kaukasiska kritcirkeln, men vi kan förstå det dialektiska spelet av motsatser. Vi kan följa tankegången hos Den goda mänskan eller Johanna fran slakthusen utan att ha varit i Kina eller Chicago. Inte Identifikation utan Emanzipation, frigörelsen från invanda tankebanor, är det centrala metodologiska greppet hos Brecht, liksom hos den kritiska historievetenskapen.

Inte går jag till Vin- och Sprithistoriska museet om jag vill berusa mig, om jag vill berusad går jag till Systembolaget. Men det verkar som om museerna idag går in för att bygga upp in- och upplevelsemättade pseudoverkligheter, låtsasverkligheter. Också här lurar medialiseringen. Risken är att museerna så snart själva blir antikvariska objekt, blir omoderna. Museifolket gör sig konkurrensberoende utåt och släpper samtidigt sin kritiska distans. Gränsen mellan konst och vetenskap suddas ut. Allt går att sälja med mördande reklam bara man drar dit Peter Dahl eller någon annan som kan bättra på den historiska verkligheten.

Det gränsar till oärlighet, till fejk och konstruktion.

Den antikvariska huvuduppgiften kan inte vara att få historien att leva när den är död - för det finns det andra, mera lämpade genrer, filmen, romanlitteraturen den måste vara att bevara den levande historien. Den som raseras med moderniteten. Problemet med den postmoderna museisynen - den avspända antiintellektualismen - är att den gör det svårare att förstå vad som har varit. Allt offras för det fantastiska, det upplevelsemässiga, för identifikationen med lidande och död, för anslutningen till ett gott syfte, vem som nu bestämmer det. Jag har svårt att begripa hur man i längden kan motivera offentliga, public service-inriktade institutioner med en sådan kultursyn. Vore det då inte logiskt att helt kapa förtöjningarna med statsbudgeten och gå in i underhållningsindustrin?

Artikeln bygger på en föreläsning vid museidagarna i Umeå april 1994. 


\section{SUMMARY}

The proper place. Some notes on museums, media and remembering

The author who is a journalist in one of the larger Swedish newspapers, has turned a critical eye on history and museums in Sweden and written many articles. This paper was presented during the "museum days» held in Umeå last April. It starts with a discussion of the journalist's role as a critical observer representing the public, when he writes or talks about museums. He refuses to accept the way media people nowadays commonly transform cultural activities into media events, robbing them of their peculiar nature and distinctive character. $\mathrm{He}$ prefers the role of the interested and involved layman and wants to define the specific character of the historical museum, its advantages as a cultural institution in comparison with e $\mathrm{g}$ historical novels and drama when communicating with the public.

He goes on to state that in places where history is alive or is trying to survive, there is no need for a museum and where there are museums, we cannot expect a living history. A corollary is that modernity is the mother of the museums. Will postmodernism bury them?

He then questions the hesitation on the part of contemporary museums to display their objects in profusion. The sparseness of objects on show, the scenographic framing in their presentation counteract the natural curiosity in the visitors. Only abundance can offer them a chance to discover for themselves patterns, regularities in the material. An important distinction is made between passive memory (prevalent) and active awareness (rare) as possible ways of dealing with the past when museums present their collections. The latter can only develop as the result of a constant active search for new knowledge in the objects. Research is an essential part of museum work and inseparable from its didactic function. As time passes, new and relevant questions must constantly be put regarding the objects. The author sees the lack of professional main obstacle to a renewal. He is also critical of the idea that the goals of museums - or of research in humanities - should be useful in terms of economic growth or industrial competitiveness. On the contrary a reflection on cultural issues based on historical research and interdisciplinarity must be the concern of museums. And the best results can be achieved not by very big museums but by competing small and lively institutions.

The paper concludes with a critical appraisal of the current aesthetic ideals. Key words in museum didactics are identity and empathy that are favoured as in classical theatre. In adherence to these concepts museums construct pseudo realities of dubious value. Brecht's Verfremdungstheorie offers an alternative akin to critical research in history. Not empathy but emancipation is the central concept in Brecht's theory and it should also be practised in museums. The problem with postmodernism is that the relaxed anti-intellectual atmosphere makes the understanding of historical realities more difficult. Everything is sacrificed to the spectacular surface, to the emotional thrill. If this is so, it should be logical for museums to give up their state-supported public service function in favour of joining the entertainment industry.

\section{REFERENSER}

Björnsson, Anders: «Säg adjö till postmodernismen!» Tvärsnitt 1991:1-2

Björnsson, Anders: «Arkiv är makt» Rikets arkiv det gamla som det nya. Arsbok for Riksarkivet och Landsarkiven (ARL) 1994(a)

Björnsson, Anders: «Hysterisk förlamning och betydelsen av en stor räfsan. Svenska Dagbladet 25/41994(b) 
ANDERS BJORNSSON

100 Björnsson, Nils: KPF 50 år. Kort historik.

Norrköping 1962

Rentzhog, Sten: «Museiprosjektet 'Den Svenska

Historien' - ambitioner och förverkligande».

Nordisk Tidsskrift 1993:3

Åkerman, Sune: Historiska museet - finns det?

Svenska Museer 1990:2

Anders Björnsson ingår i Svenska Dagbladets

redaktion och var arren 1982-93 producent vid

Sveriges Radios vetenskapsredaktion.

Adr.: Svenska Dagbladet, S-105 17 Stockholm.

Tfn: +46-813 50 54. Fax: +46-8135140. 